ДЖАБРАИЛОВ Юсуп Джабраилович - кандидат политических наук, старший научный сотрудник Регионального центра этнополитических исследований Дагестанского научного центра Российской академии наук (367032, Россия, Республика Дагестан, г. Махачкала, ул. М. Гаджиева, 45; y.djabrailov@yandex.ru)

\title{
ВНУТРИКОНФЕССИОНАЛЬНЫЕ И МЕЖЭТНИЧЕСКИЕ ОТНОШЕНИЯ В ДАГЕСТАНЕ В КОНТЕКСТЕ СОЗДАНИЯ АУХОВСКОГО РАЙОНА
}

Аннотация. Одна из точек напряжения в этноконтактной ситуации в Республике Дагестан на сегодняшний день связана с воссозданием Ауховского района. Дело в том, что разные дагестанские этносы оказались на противоположных позициях по территориальному вопросу. В статье на основе социологического интервьюирования определяются причины ухудшения межэтнических и внутриконфессиональных отношений и предлагается возможный вариант решения застарелой проблемы.

Ключевые слова: ислам, этнос, межнациональные отношения, внутриконфессиональные отношения, депортация, конфликт, территориальные споры

$\mathrm{H}$ акануне депортации чеченцев-аккинцев большинство их сел в Дагестане были объединены в Ауховский район, который был ликвидирован сразу после их депортации в 1944 г. Но вскоре на этих землях создается Новолакский район, и туда переселяются представители других дагестанских этносов. Возвращавшимся в республику после реабилитации 1957-1958 гг. чеченцамаккинцам вместо их исконных земель, которые в том же 1944 г. были заселены перемещенным с гор населением, выделены аналогичные по территории земли в Хасавюртовском, Кизилюртовском и Бабаюртовском районах.

В черте города Хасавюрта были созданы 4 поселка для устройства аккинцев: Заречный, Новый, Бамматбекюрт, Механизаторов. Аккинцам были выделены земельные участки для строительства домов, оказана значительная материальная помощь от государства [Алиев, Курбанов, Юсупова 1993: 10].

Ясного ответа на вопрос, почему дагестанские власти приняли именно такой вариант реабилитации чеченцев-аккинцев, ни у кого сегодня не существует. Все высказанные мнения на этот счет неубедительны и не встраиваются в какиелибо логические схемы.

В советский период каких-либо открытых массовых недовольств со стороны чеченцев-аккинцев не проявлялось, но внутреннее напряжение в отношении к «пришельцам» всегда сохранялось. С периода же горбачевских перемен и особенно с развалом советского государства аккинцы стали открыто требовать восстановления всех прав как реабилитированного народа. В первую очередь восстановления Ауховского района и возврата своих домов.

В связи с этим руководство республики рассматривало вопрос обмена территориями Новолакского и Хасавюртовского районов между лакцами и чеченцами-аккинцами. Но союзное руководство рекомендовало оставить все как есть, чтобы не было прецедента для Пригородного района Северной Осетии [Муслимов 2014: 27]. И вопрос с населением, юридически добровольно, но по факту принудительно переселенным, оставался открытым.

Напомним, что в 1991 г. на Третьем съезде народных депутатов Дагестана принимается решение о воссоздании Ауховского района и переносе Новолакского района в пригород Махачкалы. В этническом плане на новую территорию 
должны переселиться лакцы, а аварцы остаться проживать совместно с аккинцами. Но решение съезда о переносе Новолакского района до сих пор не реализовано в полной мере. Задержка процесса переселения связана как с социально-экономическими проблемами, так и этнополитическими процессами в республике.

Для нас представляет научный интерес вопрос переселенческой политики советского периода, ее влияния на межэтнические и внутриконфессиональные отношения, в частности в двух крупных селах -Ленинауле и Калининауле Казбековского района, - в рамках процесса воссоздания нового района. Чеченцы-аккинцы поднимают также вопрос переименования сел Калининаул и Ленинаул и включения их в состав Ауховского района. С этой целью мы в мае 2018 г. посетили эти села, побеседовали с жителями, представителями местной администрации и с имамами сел.

С этими селами сложилась особая история: Ленинаул и Калининаул (под чеченскими названиями Акташ-Аух и Юрт-Аух соответственно), входившие также в состав Ауховского района, после депортации чеченцев-аккинцев были включены в состав не Новолакского района, а соседнего Казбековского и заселены не выходцами из высокогорных районов, а жителями близлежащих аварских сел Алмак и Ихха.

Калининаул и Ленинаул расположены рядом друг с другом, и любой инцидент межэтнического характера в одном селе обязательно отражается и на другом. В настоящее время в обоих селах аварцы представлены большинством населения, чеченцы-аккинцы составляют в с. Калининаул треть населения, а в с. Ленинаул - около $40 \%$.

В целом у основной массы населения по этническому признаку нет неприязненного отношения друг к другу. За 75 лет совместного проживания между чеченцами-аккинцами и аварцами-алмакцами сложились определенные добрососедские отношения. Тем не менее назвать ординарной этноконтактную ситуацию в данных селах, сложившуюся под влиянием тягостных гонений, противостояний и взаимных обвинений, нельзя.

К усугублению межнациональных отношений ведет разделение точек зрения по вопросу о включении или невключении этих сел в состав восстанавливаемого района. На этом фоне на местах аккумулируется конфликтогенный потенциал, который периодически вспыхивает в виде драк и стычек между подростками, обвинений и оскорблений в социальных сетях.

С вхождением сел в состав Ауховского района чеченцы-аккинцы связывают восстановление исторической справедливости и гражданского равноправия. По их мнению, алмакцы изначально должны были переселиться на свои земли. На этом и сегодня настаивает один из старейшин с. Ленинаул Ахмед: «Нет никакого оправдания, чтоб в моем доме жил чужой человек. Мы не говорим, чтоб их как нас выселяли, ущемляли, истребляли, одним словом. Есть земли в других местах, пусть им дают, но нам верните наше родное. Вот это требуем, нам чужое не надо».

Чеченцы-аккинцы заявляют об ущемлении их прав по этническому принципу со стороны МВД и местных властей. Так, житель с. Ленинаул Умар говорит: «Сколько лет мы тут живем, никогда на посту главы села чеченца не было. Замы есть, но они ничего не могут решать». Раздражающим фактором для аккинцев является также стационарный пост ДПС, расположенный недалеко от села, где работают все аварцы (большинство - алмакцы). Они считают, что проверки на посту принимают избирательный характер по этническому признаку.

Алмакцы в свою очередь заявляют, что не понимают, почему аккинцы настаивают на вхождении сел Ленинаул и Калининаул в состав создаваемого 
Ауховского района, что создаст жителям только дополнительные хлопоты. Так, для решения вопросов, находящихся в компетенции муниципального района, придется делать крюк в 30 км через г. Хасавюрт, тогда как нынешний райцентр Дылым находится в 5 км от них.

Они отмечают, что заявления об ущемлении прав чеченцев-аккинцев по этническому признаку не имеют под собой никакой основы, скорее наоборот. На уровнях муниципального района и сельских поселений заместителями глав администраций являются представители чеченской национальности. Аккинцы занимают самые удобные территории, им принадлежат самые крупные магазины и заправки.

Аварцы-алмакцы подчеркивают, что их предки не добровольно, покинув свое родное село, переселились сюда и что они не раз пытались вернуться обратно, но власти, чтобы пресечь процесс возвращения, разрушили и дотла сожгли село. И они сегодня стремятся, несмотря на отсутствие взаимности, поддерживать братские отношения с чеченцами. Старшее поколение алмакцев помогало чеченцам-аккинцам в свое время обосноваться в селах, несмотря на то что правоохранительные органы строго следили за расселением чеченцев-аккинцев в рамках предоставленных им территорий.

По свидетельству жителей аварской национальности, если сегодня поднимать вопросы переименования сел и вхождения их в состав воссоздаваемого района, то будут конфликты - чеченцы-аккинцы, хотя пока официально это не озвучивают, но постоянно твердят: «Уходите, это наши земли».

В принципе алмакцы не против переименования сел, но не настроены поддерживать их вхождение в состав Ауховского района, пока не получат открыто выраженных гарантий от чеченцев-аккинцев в виде подписанных и официально обнародованных договоренностей о совместном проживании.

К настоящему времени три поколения переселенцев родились и выросли здесь, и для них эта земля стала родной. К тому же алмакцы видят, с какими проблемами столкнулось лакское население Новолакского района, когда согласилось переселиться: они уже четверть века никак не могут обустроить свой быт на выделенных территориях.

Особую обеспокоенность аварцев, проживающих в Калининауле и Ленинауле, вызывает возможность перехода Ауховского района в состав соседней Чеченской Республики. Сегодня чеченцы-аккинцы не скрывают вектор своей социально-политической ориентации на Грозный.

В истории уже был прецедент, когда в марте 1921 г. часть аккинцев открыто выразили желание выйти из состава Хасавюртовского округа ДАССР и войти в состав Чеченского округа Горской АССР. Однако тогда возобладало мнение той части аккинцев, которые были противниками выхода из состава Дагестана 1.

В апреле 1991 г. чеченцы-аккинцы уже предприняли противоправные акции в виде самозахвата земель, установления щита с гербом Чеченской Республики, надписью: «Ауховский район» при въезде в Новолакский район. В связи с обострением межнациональных отношений указом Президиума Верховного Совета ДССР от 11 сентября 1991 г. на территории Казбековского района было введено чрезвычайное положение [Алиев, Курбанов, Юсупова 1993: 18].

К тому же аккинцы, имея статус обособленного этноса, относятся к вайнахской группе населения, говорят на аккинском диалекте чеченского языка, что и обусловило возникновение конфликтной ситуации на приграничной территории не только межэтнического характера, но и межрегионального.

Как известно, представитель чеченской власти открыто предъявлял терри-

${ }^{1}$ Рукописный фонд ДНЦ РАН. Ибрагимов М.-Р. А. Акинцы в Дагестане (XVI-XX вв.). С. 304. 
ториальные претензии к Дагестану: «Никогда в жизни не забывали и не забудем, что ряд чеченских районов находится на территории Дагестана. Какое отношение, например, к Хасавюрту, Кизляру или Новолаку имеют аварцы или лезгины? Никакого отношения в историческом плане к этим городам они не имеют. Наши предки жили у Каспийского моря, мы имели свободный выход на Каспий, а через него на восток» [Кубатов 2015].

Политизация вопроса не позволила двум близким по культурным связям регионам совместными усилиями усадить за стол переговоров авторитетных представителей этнических общин, выслушать друг друга и подвигнуть к принятию компромиссных решений. Сегодня отсутствие скоординированных действий властей скорее порождает недоверие друг к другу и ведет ситуацию в тупиковое состояние. Какие-либо уступки в требованиях, без которых невозможно достичь компромисса, рассматриваются как слабость позиции или предательство своих этнических интересов.

Сельские общины Калининаула и Ленинаула разделились по этническому признаку в совершении культовых обрядов и молитв. Аккинцы считают недозволенной и запретной молитву в мечетях, построенных на «самозахваченной» территории, но в то же время не пускают аварцев в «свои» мечети, тогда как в исламе мечеть считается домом Всевышнего Аллаха, и любой мусульманин имеет право совершать в ней молитву.

Нужно сказать, что все имамы практически разделяют этнические позиции. Имам «чеченской» мечети с. Ленинаул прямо заявляет, что не поддержит никакие совместные общественные мероприятия, пока не будет решен вопрос создания Ауховского района. Имам «аварской» мечети села заявляет, что у него нет никаких контактов с ним.

В этом плане значительно отличается ситуация в с. Калининаул. Имамы обеих мечетей контактируют между собой, и в «чеченской» мечети следуют общедагестанскому временному графику совершения молитв (рузнама). Здесь есть понимание того, что найти выход из замкнутого круга могут фактически только религиозные деятели, опираясь на единые ценности. Но, к сожалению, даже мелкие ссоры и конфликты с этническим подтекстом могут активизировать дремлющие исторические претензии друг к другу. (Показательно в этом плане отсутствие брачных союзов между алмакцами и акинцами, за исключением нескольких семейных пар в селении Калининаул.)

Имам «чеченской» мечети с. Калининаул отмечает: «В последние годы с ростом религиозности населения межэтническая ситуация стабилизировалась, ранее были часты ссоры и драки чуть ли не каждый месяц. Если бы не единая религия и соответствующие общие ценности, помогающие находить точки соприкосновения, то предотвращать массовые столкновения было бы практически невозможно».

Имамы едины во мнении, что все жители устали от этого тревожного состояния. Но есть в селе активисты с двух сторон, благодаря которым любой мелкий конфликт раздувается до значительного общественного резонанса.

По мнению имама «аварской» мечети с. Ленинаул, провокации устраивают в основном силы извне. Он имеет ввиду инициативную группу, которая на постоянной основе занимается привлечением внимания республиканских и федеральных властей к созданию Ауховского района и включению в его состав сел Калининаул и Ленинаул.

Так, в 2017 г. подрались школьники. Это обычное явление в таком возрасте, но оно переросло в самое резонансное противостояние между чеченцамиаккинцами и аварцами-алмакцами за последние годы. Спустя две недели жители Чеченской Республики, возмущенные сообщениями в социальных 
сетях о якобы ущемлении чеченцев-аккинцев в с. Ленинаул, в составе большой колонны автомобилей двинулись в его сторону. В этот напряженный период имамы собрали аварскую молодежь обоих сел в клубе, прочитали проповеди на тему единства в исламе и ущербности межнациональных конфликтов. И люди послушали имамов, они не вышли из села, не поддались на провокационные высказывания в их адрес.

Имам «аварской» мечети с. Ленинаул рассказал также, что к его супруге (она имеет высшее исламское образование) приходят соседки-чеченки для обучения основам религии. Так, он сказал: «После конфликта 2017 года они перестали ходить, думая, что мы не примем больше их, но я сразу отправил супругу, чтобы они из-за мелочных конфликтов не оставляли обучение религии. Они, когда им так сказали, просто заплакали. У нас нет межэтнической неприязни, я даже радуюсь, что они приходят в наш дом за религиозными знаниями».

Все имамы согласны с тем, что общие исламские ценности играют огромную роль в стабилизации межэтнических отношений и в разрешении постконфликтной ситуации. Властям и политикам с обеих сторон люди не доверяют, в их словах они ищут определенный подвох, хитрость и коварство.

По этническому принципу разошлись жители сел во мнении об институтах, ухудшающих этноконтактную ситуацию. Так, алмакцы к таковым, наряду с социальными сетями, отнесли институт старейшин, воспитывающих молодое поколение в духе враждебности. Дело в том, что культурные образцы, питающие межэтническую напряженность, не изживаются полностью в период относительного благополучия. В основном тяготы жертв этнических гонений воспроизводятся в форме семейных историй именно старшим поколением. По мнению аккинцев, на ухудшение межэтнических отношений влияют высокопоставленные выходцы из села, а также сказывается превалирующий демографический рост молодого поколения переселенцев, считающих данную землю своей родиной.

Численное доминирование алмакцев требует обязательного согласования с ними позиций, касающихся вопросов статуса муниципального образования, поскольку современное законодательство в области местного самоуправления ставит заслон любым изменениям границ муниципального образования, их преобразованиям без согласия местного населения.

Но чеченцы-аккинцы ссылаются на закон «О реабилитации репрессированных народов» и игнорируют все посреднические шаги Министерства по национальной политике РД, местных властей и дагестанского духовенства.

Вместе с тем в законе «О реабилитации репрессированных народов» указывается, что восстановление и изменение национально-государственных образований репрессированных народов осуществляется на основе законодательного регулирования межнациональных отношений, но механизм реализации самого закона не был тщательно разработан. Именно поэтому в условиях отсутствия в стране правового механизма урегулирования межнациональных отношений принятие данного закона привело к возникновению ряда трудноразрешимых проблем [Алиев, Курбанов, Юсупова 1993: 13].

Таким образом, мы пришли к выводу, что напряжение этноконтактной ситуации и наличие «этнических мечетей» в муниципалитетах связано исключительно с территориальными спорами, вызванными в результате переселений советского периода. Разговоры о существовании конфессиональных противоречий между аккинцами и алмакцами не имеют какого-либо основания. Оба этноса являются мусульманами-суннитами и придерживаются норм шафиитской правовой школы ислама. Здесь с обеих сторон явно просматривается при- 
оритет этнических, политических и социально-экономических интересов над конфессиональными.

В ситуации, когда противоречивые точки зрения подкреплены теми или иными законодательными нормами и в распоряжении у государства нет ясного представления о пути разрешения конфликтной ситуации, естественно, необходимо в первую очередь наладить диалог сторон.

Такую посредническую роль способна взять на себя только комиссия федерального уровня. Основным направлением деятельности комиссии должно быть согласование требований жителей и последующее проведение открытой региональной конференции по вопросам создания Ауховского района Республики Дагестан, включения или невключения в его состав сел Калининаул и Ленинаул, изменения их названий, территориальной целостности и т.д.

\title{
Список литературы
}

Алиев А.К., Курбанов М.Р., Юсупова Г.И. 1993. Чеченцы-аккинцы Дагестана: к проблеме реабилитации. Махачкала: РЦЭПИ ДНЦ РАН. 60 с.

Кубатов Д. 2015. Сайгидпаша Умаханов. Хранитель северных ворот. Доступ: http://kavpolit.com/blogs/kubatov/19320 (проверено 30.09.2018).

Муслимов Т.К. 2014. Национальный вопрос в Дагестане: история, современные проблемы и концепции. Махачкала: РЦЭПИ ДНЦ РАН. 61 с.

\section{INTRA-CONFESSIONAL AND INTER-ETHNIC RELATIONS IN DAGESTAN IN THE CONTEXT OF CREATION OF THE AUKH DISTRICT}

\begin{abstract}
One of the points of tension in the ethno-contact situation in the Republic of Dagestan today is connected with reconstruction of the Aukh District. The matter is that different Dagestan ethnoses found themselves in controversial positions on the territorial issue. The article on the base of sociological interviewing identifies the reasons of deterioration in the interethnic and intra-confessional relations and suggests the possible version of the solution to an old problem.

Keywords: Islam, ethnos, inter-ethnic relations, intra-confessional relations, deportation, conflict, territorial disputes
\end{abstract}

